\title{
Mini-open Versus Arthroscopic Rotator Cuff Repair: A Comparison of Clinical Results and Re-tear Rates by Magnetic Resonance Arthrogram
}

\author{
Mini-açık ve Artroskopik Rotator Manşet Onarımı: Klinik Sonuçların ve Manyetik \\ Rezonans Artrogram ile Yeniden Yırtılma Oranlarının Karşılaştırılması \\ ๑ Mehmet Ali Talmaç, ๑ Mehmet Akif Görgel, ๑ Mehmet Ali Bozca, ๑ Alp Arya*, \\ (1) Mehmet Mesut Sönmez** , ๑ Hacı Mustafa Özdemir \\ University of Health Sciences, Şişli Hamidiye Etfal Training and Research Hospital, Clinic of Orthopaedics and Traumatology, \\ istanbul, Turkey \\ *istanbul Surgical Hospital, Clinic of Orthopaedics and Traumatology, Istanbul, Turkey \\ **University of Health Sciences, Haseki Training and Research Hospital, Clinic of Orthopaedics and Traumatology, Istanbul, Turkey
}

\section{Abstract}

\begin{abstract}
Aim: The aim of this study was to compare the re-tear rates and clinical results between mini-open and full arthroscopic techniques of the rotator cuff repair.
\end{abstract}

Methods: We retrospectively reviewed a total of 82 patients. Mini-open and full arthroscopic techniques were performed in 30 patients (group MO) and 52 patients (group A), respectively. The main outcome measurements were the University of California at Los Angeles (UCLA) and American Shoulder and Elbow Surgeons (ASES) scores, abduction and external rotation strengths $(\mathrm{kg})$, and re-tear rate on magnetic resonance arthrography. All variables were compared between the groups.

Results: The mean age of all patients included in the study was $55.4 \pm 6.1$ years. Sixty (73.2\%) patients were female. The mean follow-up was $12.3 \pm 1.4$ months. The mean UCLA and ASES scores and external rotation strength in group A were significantly higher than in group $\mathrm{MO}$. The mean abduction strengths were similar. There was no statistically significant difference in terms of re-tear rates.

Conclusion: Rotator cuff tears can be successfully treated with either mini-open or arthroscopic techniques. Although there was no statistically significant difference in re-tear rates, full arthroscopic repair had better functional outcomes.

Keywords: Arthrography, arthroscopy, rotator cuff tears, shoulder

\section{Öz}

Amaç: Bu çalışmanın amacı, rotator manşet onarımının mini açık ve tam artroskopik teknikleri arasındaki tekrar yırtılma oranlarını ve klinik sonuçları karşılaştırmaktı.

Yöntemler: Toplam 82 hastayı retrospektif olarak inceledik. Mini-açık ve tam artroskopik teknikler sırasıyla 30 (grup MO) ve 52 (grup A) hastaya uygulandı. Ana sonuç ölçümleri, Los Angeles Kaliforniya Üniversitesi (UCLA) ve Amerikan Omuz ve Dirsek Cerrahları (ASES) skorları, abduksiyon ve dış rotasyon güçleri $(\mathrm{kg})$ ve manyetik rezonans artrogramda yeniden yırtılma oranı idi.

Bulgular: Çalışmaya alınan tüm hastaların yaş ortalaması $55,4 \pm 6,1$ yıl idi. Altmış $(\% 73,2)$ hasta kadındı. Ortalama takip süresi 1,3 $\pm 1,4$ aydı. A grubunun ortalama UCLA ve ASES skorları ve ortalama dış rotasyon gücü MO grubundan anlamlı olarak yüksekti. Ortalama abduksiyon güçleri benzerdi. Yeniden yırtılma oranları açısından istatistiksel olarak anlamlı fark yoktu.

Sonuç: Rotator manşet yırtılmaları mini-açık veya artroskopik tekniklerle başarıyla tedavi edilebilir. Yeniden yırtılma oranları açısından istatistiksel olarak anlamlı bir fark olmamasına rağmen, tam artroskopik tamir daha iyi fonksiyonel sonuçlara sahiptir.

Anahtar Sözcükler: Artrografi, artroskopi, omuz, rotator manşet yırtıkları
Address for Correspondence/Yazışma Adresi: Mehmet Ali Talmaç, University of Health Sciences, Şişli Hamidiye Etfal Training and Research Hospital, Clinic of Orthopaedics and Traumatology, İstanbul, Turkey

Phone: +90 5555529329 E-mail: drtalmac2@gmail.com ORCID: orcid.org/0000-0001-7734-6438

Received/Geliş Tarihi: 15 March 2019 Accepted/Kabul Tarihi: 15 March 2019
${ }^{\circ}$ Copyright 2019 by The Medical Bulletin of istanbul Haseki Training and Research Hospital The Medical Bulletin of Haseki published by Galenos Yayınevi. 'Telif Hakkı 2019 istanbul Haseki Eğitim ve Araştırma Hastanesi Haseki Tıp Bülteni, Galenos Yayınevi tarafından yayınlanmıştır. 


\section{Introduction}

Rotator cuff tears are one of the most common cause of morbidity affecting the shoulder (1). Surgery should be performed for patients with functional impairment and persistent pain (2). However, despite surgery re-tear rates varying between $13 \%$ and $68 \%$ have been reported in the literature (3-5). Re-tear may be associated with a poor result (6).

Rotator cuff repair can be performed with various techniques $(1,7,8)$. Although full arthroscopic rotator cuff repair is considered the gold standard (9), functional outcomes and re-tear rates are still conflicting when compared with the mini-open technique $(1,7,10)$. In addition, many studies have evaluated re-tear rates with non-contrast magnetic resonance imaging $(4,5)$.

In the present study, we aimed to compare re-tear rates using magnetic resonance (MR) arthrography and clinical results between mini-open and full arthroscopic repair techniques.

\section{Methods}

After approval of the institutional review board (08.01.2019/1131), informed consent was obtained from all individual participants included in the study.

We performed a retrospective analysis of two groups of patients. We found a total of 104 patients $\geq 40$ years of age who were operated for rotator cuff tear in our clinic between January 2016 and January 2018. The patients were selected carefully in order to eliminate confounding pathologies. Table 1 represents our inclusion and exclusion criteria. After eliminating patients with confounding lesions, a total of 82 patients were included in the study. Mini-open and full arthroscopic techniques were used

in 30 patients (group $\mathrm{MO}$ ) and 52 patients (group A), respectively.

Preoperative properties of patients included age, sex, body mass index (BMl; $\left.\mathrm{kg} / \mathrm{m}^{2}\right)$, affected side, trauma history, and follow-up duration. Postoperative results at last follow-up included University of California at Los Angeles (UCLA) and American Shoulder and Elbow Surgeons (ASES) scores $(11,12)$, abduction and external rotation strengths $(\mathrm{kg})$, and re-tear rate on MR arthrography. All preoperative properties and postoperative results were compared between the two groups. MR arthrography was used to evaluate postoperative rotator cuff integrity (Figure 1).

\begin{tabular}{|l|l|}
\hline \multicolumn{2}{|l|}{ Table 1. Inclusion and exclusion criteria } \\
\hline Inclusion criteria & Exclusion criteria \\
\hline Age $\geq 40$ years & SLAP lesion \\
\hline $\begin{array}{l}\text { Moderate or large (1-5 } \\
\text { cm) rotator cuff tears }\end{array}$ & Hill-Sachs lesion \\
\hline $\begin{array}{l}\text { Written informed } \\
\text { consent }\end{array}$ & Labral tears \\
\hline \multirow{5}{*}{} & Hagl lesion \\
\hline & Glenohumeral arthrosis \\
\cline { 2 - 3 } & Massive rotator cuff rupture $(>5 \mathrm{~cm})$ \\
\hline & Brachial plexopathy \\
\hline & Suprascapular neuropathy \\
\hline & Bilateral rotator cuff tear \\
\cline { 2 - 3 } & $\begin{array}{l}\text { Previous ipsilateral upper extremity surgery } \\
\text { Cognitive impairment }\end{array}$ \\
\cline { 2 - 3 } & Death in follow-up \\
\hline & A follow-up period of less than 6 months \\
\hline SLAP: Superior labral tear from anterior to posterior \\
\hline
\end{tabular}
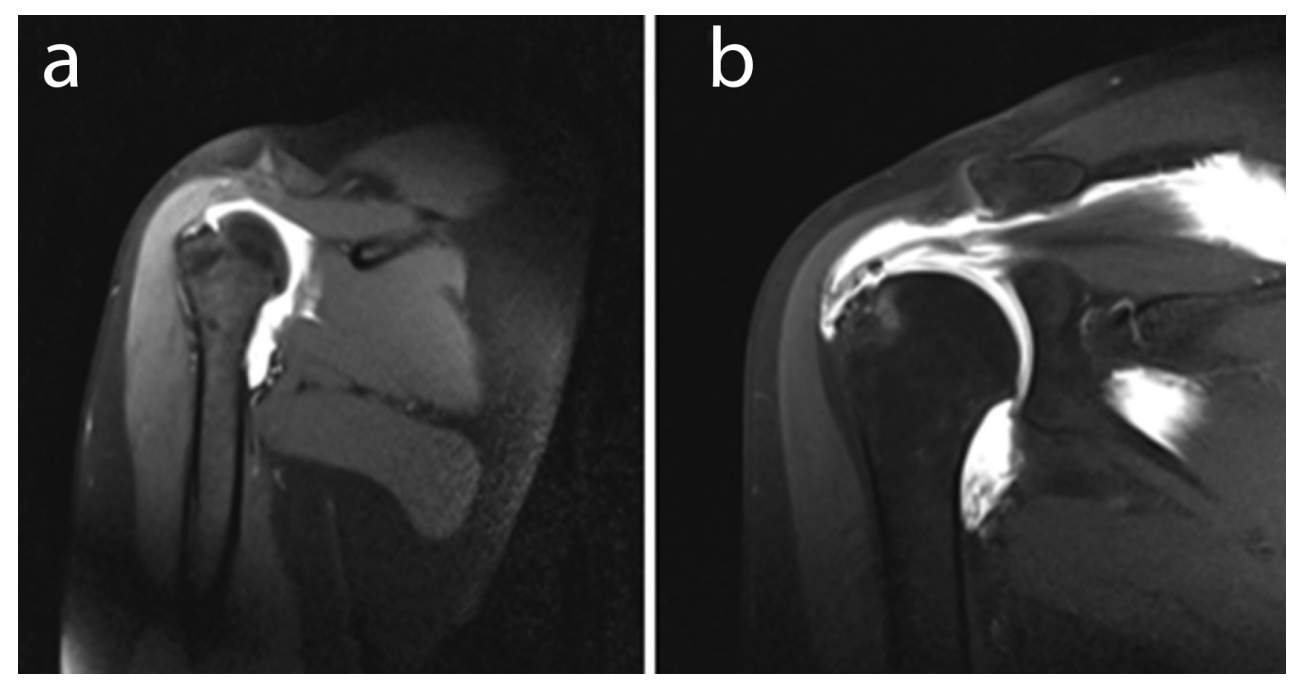

Figure 1. Re-tear images in coronal magnetic resonance arthrograms of patients who underwent rotator cuff repair with full arthroscopic (a) and mini-open (b) techniques 
Ethics committee approval was obtained from the University of Health Sciences Şişli Hamidiye Etfal Training and Research Hospital Clinical Researches Committee (no: 2206) and informed consent was obtained from all patients.

\section{Surgical Technique}

All procedures were performed in the beach-chair position. In both groups, the surgeon initially evaluated patients arthroscopically.

Patients undergoing mini-open technique underwent initial arthroscopic subacromial evaluation and if needed decompression of the joint. After subacromial bursectomy and debridement of the rotator cuff, the tear size was evaluated. Then the anterolateral portal was extended 3 to $4 \mathrm{~cm}$ for a mini-open procedure. After splitting the deltoid, the humeral head was exposed. Using a burr, a superficial abrasion of the greater tuberosity was performed. Two or three bioabsorbable suture anchors were placed in the footprint area. Using a free needle, sutures were passed and secured through the tendon with simple stitches. All knots were tied with four alternating hitches. The deltoid and skin were closed in a standard fashion.

For arthroscopic technique, the initial subacromial evaluation and decompression were identical to that performed for the mini-open procedure. Using two bioabsorbable anchors and two metal anchors, the double-row technique was initiated for the repair. After passing sutures through the tendon, all knots were tied with four alternating half hitches. The postoperative rehabilitation regimen was identical to that for the miniopen group.

The postoperative rehabilitation protocol for both techniques included a period of immobilization for 3-6 weeks postoperatively, followed by an active range-ofmotion program at 3-6 weeks and strengthening at 6-12 weeks (6). The characteristic features of the tear were evaluated intra-operatively. Patients with a non-retracted rotator cuff tear, $1-3 \mathrm{~cm}$ or $3-5 \mathrm{~cm}$ in size, were included in the study.

\section{Statistical Analysis}

SPSS 15.0 (SPSS Inc., Chicago, IL, USA) was used for statistical analysis. Descriptive statistics were given as number and percentage for categorical variables and were given as mean and standard deviation for numerical variables. The independent two group comparisons were made by the Mann-Whitney $U$ test because the numerical variables did not meet the normal distribution. Dependent group comparisons were made with the Wilcoxon test when numerical variables differences did not meet normal distribution and with the paired samples t-test when differences of numerical variables provided normal distribution. The ratios in the groups were compared with the chi-square test. A $p$ value of less than 0.05 was considered statistically significant.

\section{Results}

The mean age of all patients included in the study was $55.4 \pm 6.1$ years. Sixteen $(73.2 \%)$ patients were female. Thirty-eight $(46.3 \%)$ patients had rotator cuff tear in the right shoulder. The mean follow-up was $12.3 \pm 1.4$ months. Preoperative properties of the patients are shown in Table 2. The mean age, BMI, follow-up duration, gender and affected side distribution, and rate of trauma history were similar between the groups.

Clinical and MR arthrography results were evaluated at the end of the follow-up. The mean UCLA and ASES scores and external rotation strength in group A were significantly higher than in group $\mathrm{MO}$. The mean abduction strengths were similar between the groups. Although, evaluation of the MR arthrography results revealed a higher rate of re-tear in all-arthroscopic repair than miniopen repair for rotator cuff tears, there was no statistically significant difference. Comparison of postoperative results is summarized in Table 3.

\begin{tabular}{|c|c|c|c|}
\hline Variable & $\begin{array}{l}\text { Group MO } \\
(n=30)\end{array}$ & $\begin{array}{l}\text { Group A } \\
(n=52)\end{array}$ & $\mathbf{p}$ \\
\hline Age (year); (mean \pm SD) & $55.3 \pm 7.2$ & $55.5 \pm 5.4$ & 0.958 \\
\hline Male/Female; $\mathbf{n}$ & $8 / 22$ & $14 / 38$ & 0.980 \\
\hline BMI $\left(\mathrm{kg} / \mathrm{m}^{2}\right) ;($ mean \pm SD) & $32.3 \pm 4.3$ & $30.2 \pm 5.4$ & 0.114 \\
\hline Right/Left; n & $16 / 14$ & $22 / 30$ & 0.335 \\
\hline Trauma history; n (\%) & $2(6.7)$ & $2(3.8)$ & 0.621 \\
\hline $\begin{array}{l}\text { Follow-up duration } \\
\text { (months); (mean } \pm \text { SD) }\end{array}$ & $11.9 \pm 1.5$ & $12.4 \pm 1.4$ & 0.141 \\
\hline
\end{tabular}

SD: Standard deviation, n: number of the patients, BMI: Body mass index, $\mathrm{kg}$ : Kilogram, \%: percentage

\begin{tabular}{|l|l|l|l|}
\hline \multicolumn{4}{|l|}{ Table 3. Comparison of postoperative results } \\
\hline Variable & $\begin{array}{l}\text { Group MO } \\
\mathbf{( n = 3 0 )}\end{array}$ & $\begin{array}{l}\text { Group A } \\
\mathbf{( n = 5 2 )}\end{array}$ & $\mathbf{p}$ \\
\hline UCLA score; (mean \pm SD) & $28.6 \pm 2.0$ & $30.1 \pm 1.8$ & 0.002 \\
\hline ASES score; (mean \pm SD) & $89.7 \pm 1.9$ & $91.5 \pm 3.8$ & 0.015 \\
\hline $\begin{array}{l}\text { Abduction strength (kg); } \\
\text { (mean } \pm \text { SD) }\end{array}$ & $5.06 \pm 0.36$ & $5.12 \pm 0.30$ & 0.529 \\
\hline $\begin{array}{l}\text { External rotation strength } \\
\text { (kg); (mean } \pm \text { SD) }\end{array}$ & $5.55 \pm 0.18$ & $5.78 \pm 0.33$ & $<0.001$ \\
\hline $\begin{array}{l}\text { Re-tear in MR arthrography; } \\
\mathbf{n}(\%)\end{array}$ & $4(13.3)$ & $14(26.9)$ & 0.152 \\
\hline $\begin{array}{l}\text { UCLA: The University of California at Los Angeles, ASES: American Shoulder } \\
\text { and Elbow Surgeons, SD: Standard deviation, MR: Magnetic resonance, kg: } \\
\text { Kilogram, n: Number of the patients, \%: percentage }\end{array}$ \\
\hline
\end{tabular}




\section{Discussion}

Since the implementation of the all-arthroscopic rotator cuff repair technique, there have been considerable discussions over the benefits of this procedure compared to the mini-open technique $(13,14)$. The all-arthroscopic repair technique is a popular modality for the treatment of rotator cuff tears and it is becoming more popular as the number of experienced surgeons in the field continues to increase (15). The necessity of acromioplasty during rotator cuff repair is controversial (16). However in our opinion, it will provide a better surgical view of the space for the rotator cuff tendons. In our study, anteroinferior acromioplasty procedure was performed in all patients.

In the literature, the age of patients who underwent rotator cuff repair remains between 54 and 66 years and more than half of the patients are female $(1,17)$. The present study demonstrated that the mean age and gender distribution in both groups were similar and consistent with the literature. Bayle et al (7). reported that the etiology of rotator cuff tear was trauma in $30 \%$ of 87 patients. However, we found that only four of 82 patients had a history of trauma.

In many studies which evaluated rotator cuff tears, UCLA and ASES shoulder scores were used as a clinical outcome measurement $(10,18)$. Zhang et al (1). reported that UCLA and ASES shoulder scores were similar between two techniques. However, in this study, UCLA and ASES shoulder scores were significantly higher than mini-open repair.

Other clinical outcome measurements of our study were abduction and external rotation strengths $(\mathrm{kg})$. In accordance with the literature, we found that the mean abduction strength was similar between the groups. However, this study demonstrated that all-arthroscopic group had more external rotation strength.

These results suggested that the all-arthroscopic technique is superior to mini-open in terms of clinical outcomes.

In a systematic review by Bedeir et al (19)., the retear rate for arthroscopic repair of rotator cuff tear was evaluated. They reviewed 14 studies with a total of 260 rotator cuff re-tears and found that the re-tear rate for the double-row technique was $43 \%$. Zhang et al. (1) reported that the incidence of re-tear was higher in patients undergoing arthroscopic rotator cuff repair than in those operated using the mini-open technique. However, in our study, the re-tear rate for all patients was $22 \%$ and there was not a statistically significant difference between the groups.

\section{Study Limitations}

Despite our informative findings, this study has some limitations, including its retrospective design, relatively small sample size, as well as the lack of subgroup analysis of patients according to moderate and large rotator cuff tears, and lack of post-hoc power analysis. However, the most important strength of this study was the single-center setting.

\section{Conclusion}

The present study indicates that moderate to large rotator cuff tears can be successfully treated with either mini-open or arthroscopic techniques. Although there was no statistically significant difference in terms of retear rates, full arthroscopic repair has better functional outcomes in terms of UCLA and ASES scores and external rotation strength.

\section{Authorship Contributions}

Surgical and Medical Practices: M.M.S. Concept: M.A.T. Design: A.A., M.A.B. Data Collection or Processing: M.A.G. Analysis or Interpretation: M.M.S. Literature Search: M.A.G., H.M.Ö. Writing: M.A.T., M.A.G.

Conflict of Interest: No conflict of interest was declared by the authors.

Financial Disclosure: The authors declared that this study received no financial support.

\section{References}

1. Zhang Z, Gu B, Zhu W, et al. Arthroscopic versus miniopen rotator cuff repair: a prospective, randomized study with 24-month follow-up. Eur J Orthop Surg Traumatol 2014;24:845-50.

2. Carr A, Cooper C, Campbell MK, et al. Effectiveness of open and arthroscopic rotator cuff repair (UKUFF): a randomised controlled trial. Bone Joint J 2017;99-B:107-15.

3. Harryman DT 2nd, Mack LA, Wang KY, Jackins SE, Richardson $\mathrm{ML}$, Matsen FA 3rd. Repairs of the rotator cuff. Correlation of functional results with integrity of the cuff. J Bone Joint Surg Am 1991;73:982-9.

4. Bishop J, Klepps S, Lo IK, et al. Cuff integrity after arthroscopic versus open rotator cuff repair: a prospective study. J Shoulder Elbow Surg 2006;15:290-9.

5. Boileau P, Brassart N, Watkinson DJ, et al. Arthroscopic repair of full-thickness tears of the supraspinatus: does the tendon really heal? J Bone Joint Surg Am 2005;87:1229-40.

6. Fehringer EV, Sun J, VanOeveren LS, et al. Full-thickness rotator cuff tear prevalence and correlation with function and co-morbidities in patients sixty-five years and older. J Shoulder Elbow Surg 2008; 17:881-5.

7. Bayle X, Pham TT, Faruch M, et al. No difference in outcome for open versus arthroscopic rotator cuff repair: a prospective comparative trial. Arch Orthop Trauma Surg 2017;137:170712.

8. Porto Fde M, Alves MW, de Andrade AL. Evaluation of patients undergoing rotator cuff suture with the modified mason-allen technique. Acta Ortop Bras 2013;21:167-9. 
9. Randelli $P$, Cucchi $D$, Ragone $V$, et al. History of rotator cuff surgery. Knee Surg Sports Traumatol Arthrosc 2015;23:34462.

10. Yang J Jr, Robbins M, Reilly J, et al. The Clinical Effect of a Rotator Cuff Retear: A Meta-analysis of Arthroscopic Single-Row and Double-Row Repairs. Am J Sports Med 2017;45:733-41.

11. Nutton RW, McBirnie JM, Phillips C. Treatment of chronic rotator-cuff impingement by arthroscopic subacromial decompression. J Bone Joint Surg Br 1997;79:73-6.

12. Michener LA, McClure PW, Sennett BJ. American Shoulder and Elbow Surgeons Standardized Shoulder Assessment Form, patient self-report section: reliability, validity, and responsiveness. J Shoulder Elbow Surg 2002;11:587-94.

13. Kim SH, Ha Kl, Park JH, et al. Arthroscopic versus mini-open salvage repair of the rotator cuff tear: outcome analysis at 2 to 6 years' follow-up. Arthroscopy 2003;19:746-54.

14. Tauro JC. Arthroscopic rotator cuff repair: analysis of technique and results at 2- and 3-year follow-up. Arthroscopy 1998;14:45-51.
15. Ji X, Bi C, Wang F, et al. Arthroscopic versus mini-open rotator cuff repair: an up-to-date meta-analysis of randomized controlled trials. Arthroscopy 2015;31:118-24.

16. Sun Z, Fu W, Tang $X$, et al. Systematic review and Metaanalysis on acromioplasty in arthroscopic repair of fullthickness rotator cuff tears. Acta Orthop Belg 2018;84:5461.

17. Tudisco C, Bisicchia S, Savarese E, et al. Single-row vs. doublerow arthroscopic rotator cuff repair: clinical and 3 Tesla MR arthrography results. BMC Musculoskelet Disord 2013;14:43.

18. Boyer P, Bouthors C, Delcourt T, et al. Arthroscopic double-row cuff repair with suture-bridging: a structural and functional comparison of two techniques. Knee Surg Sports Traumatol Arthrosc 2015;23:478-86.

19. Bedeir YH, Schumaier AP, Abu-Sheasha G, et al. Type 2 retear after arthroscopic single-row, double-row and suture bridge rotator cuff repair: a systematic review. Eur J Orthop Surg Traumatol 2019;29:373-82. 